\title{
Mean Platelet Volume Level in Patients with Ankylosing Spondylitis and its Relationship with Disease Activity and Presence of Cardiovascular Risk Factors
}

Nilgun Ustun ${ }^{1}$, Alper Murat Ulasli², Ihsan Ustun³ ${ }^{3}$ Erkan Yula ${ }^{4}$, Abdullah Erman Yagiz $^{1}$, Hayal Guler ${ }^{1}$

\begin{abstract}
This study was conducted to compare mean platelet volume (MPV) in ankylosing spondylitis (AS) patients with that of healty controls, analyze the effect of disease status and presence of traditional cardiovascular risk factors (CRF) such as smoking, hypertension, hyperlipidemia, diabetes and obesity. Retrospectively, 152 patients with AS were included. The control group included 55 sex-and age-matched healty subjects without any risk factors and concomitant diseases. MPV level in AS patients was higher than healthy controls, MPV and PLT levels in AS patients with at least on one traditional CRF were not significantly different compared to patients without any risk factor. MPV showed no significant association with any disease activity. There was no significant difference between active and inactive state in AS patients according to MPV. Patients have higher MPV than healthy controls indicating higher risk of cardiovascular involvement and atherosclerosis. AS alone may be responsible of this increment instead of traditional CRF's.
\end{abstract}

Key words: ankylosing spondylitis, mean platelet volume, cardiovascular disease, disease activity

\section{Ankilozan Spondilitli Hastalarda Ortalama Platelet Hacmi ve Hastalık Aktivitesi ve Kardiyovaskuler Risk} Faktörleri Varlığıyla ilișkisi

ÖZET

Bu çalıșma, sağlıklı kontrollerle ile ankilozan spondilit (AS) hastalarda ortalama trombosit hacmini (MPV) karșılaștırmak, hastalık durumu ile sigara, hipertansiyon, hiperlipidemi, diyabet ve obezite gibi geleneksel kardiyovasküler risk faktörleri (KBY) varlığının etkisini analiz etmek için yapılmıștır. Retrospektif olarak AS'li 152 hasta çalıșmaya alındı. Kontrol grubu olarak herhangi bir risk faktörleri ve eșlik eden hastalıkları olmayan, cinsiyet ve yașları eșleștirilmiș 55 sağlıklı kiși alındı. AS hastalarının MPV düzeyleri kontrol grubundan yüksekti. En az bir geleneksel kardiyovasküler risk taşıyan AS hastalarında MPV ve PLT düzeyleri sağlıklı kontrol grubu ile karșılaștırıldığında anlamlı farklılık yoktu. MPV herhangi bir hastalık aktivitesi ile anlamlı ilișki göstermedi. MPV aktif ve inaktif duruma göre AS hastalarında anlamlı farklılık bulunmadı. Hastalar kardiyovasküler tutulum ve ateroskleroz riski daha yüksek olan kontrol grubuna göre daha yüksek MPV değerine sahipti. AS tek bașına geleneksel kardiyovasküler risk faktörlerinden bağımsız olarak bu artıștan olabilir.

Anahtar kelimeler: Ankilozan spondilit, ortalama platelet hacmi, kardiyovaskuler hastalık, hastalık aktivitesi

\footnotetext{
Department of General Surgery, Kecioren Training and Research Hospital Ankara Turkey, ${ }^{2}$ Department of Gastroenterology, Çanakkale Public Hospital, Ankara, Turkey, ${ }^{3}$ Department of Surgery, Yıldırım Beyazıt University, Faculty of Medicine, Ankara, Turkey, ${ }^{4}$ Department of Gastroenterology, Hacettepe University, Faculty of Medicine, Ankara , ${ }^{5}$ Department of Radiology, Canakkale Onsekizmart University Hospital, Faculty of Medicine, Çanakkale
}

Correspondence: Erdem Koçak,

Keklikpınarı mahallesi, 240 sokak, Duru apartmanı, 8/6, Dikmen, Çankaya, Ankara, Turkey

Telephone: +90-312-4768147 e-mail: kocak67@hotmail.com 


\section{INTRODUCTION}

Ankylosing spondylitis (AS) is one of the most common chronic inflammatory disorder associated with enhanced cardiovascular disease (1-4). The mortality rate for patients with AS is approximately twice that of the general population and the majority of this increase is attributed to cardiovascular disease (5). Traditional cardiovascular risk factors (CRF) are also more common in patients with AS than in matched controls (3). Patients with AS have been found to have a higher rate of dyslipidemia, metabolic syndrome and hypertension (6-8).

Novel findings suggest that chronic systemic inflammation, at least in part, contribute to formation and progression of atherosclerotic plaque and cardiovascular involvement in AS (8-9). Chronic inflammation is associated with the persistent elevation of proinflammatory marker levels, such as tumor necrosis factor a (TNF a, interleukin-6, and C-reactive protein (CRP), which are associated with an increased risk of atherosclerosis and arterial thrombosis (6-9). Platelets have a major effect on the formation of atherosclerotic plaques and consequently play an essential role in the pathogenesis of atherothrombosis (10). Larger platelets were found to be more reactive and produce more trombotic factors such as thrombaxane A2 $(11,12)$. Thus, mean platelet volume (MPV) has been proposed as an indirect marker of increased platelet reactivity $(13,14)$. High-grade inflammatory diseases, such as rheumatoid arthritis and psoriasis present with high levels of MPV, which reverse in the course of anti-inflammatory therapy $(15,16)$. Recently, larger and functionally more reactive platelets have been found in patients with diabetes mellitus, hypertension, dyslipidemia, obesity and in smokers (17-22). Increased platelet aggregability have been reported to be an independent risk factor for cardiovascular events (13). Increased MPV was also observed in Behçet's disease patients with thrombosis (23). The pathogenesis of cardiovascular disease in patients with AS may be linked to an increased prothrombotic activity which might be evaluated by MPV $(24,25)$.

Previously, in a small number of studies MPV was reported to be higher in active AS patients compared to controls and it was decreased in response to treatment (15, 26). However, in these studies other possible causes of higher MPV such as hypertension, hyperlipidemia, diabetes mellitus, smoking status were not taken into consideration in patients with AS. In this regard for better understanding the role of MPV in cardiovascular involvement in AS patients, this study was conducted to compare MPV in AS patients with that of healthy controls, analyze the difference in MPV between AS patients with active and inactive disease status and investigate the difference in MPV between AS patients with and without traditional CRF's such as smoking, hypertension, hyperlipidemia, diabetes and obesity.

\section{MATERIALS AND METHODS}

After retrospective analyze of the hospital records between January 2010 and December 2012, a total of 152 patients with AS fullfilling the the modified New York criteria (27), whose complete clinical data including symptoms, past medical history, smoking habits, laboratory records (Complete blood count (CBC), Bath Ankylosing Spondylitis Disease Activity Index (BASDAI) scores, erythrocyte sedimentation rate (ESR), CRP, platelet count (PLC) and MPV) could be obtained were enrolled. The control group included 55 sex-and age-matched healty subjects without any risk factors and concomitant diseases who were admitted to outpatient clinics for routine check-up. So, blood samples for CBC were also taken from control group. Besides demographic and disease-spesific data, traditional CRF (smoking, hypertension, high cholesterol, diabetes and obesity) were also noted. Smoking was identified as being a current smoker. Hypertension was defined as current use of antihypertensive medication. LDL cholesterol > $130 \mathrm{mg} / \mathrm{dL}-1$ or total cholesterol > $200 \mathrm{mg} \cdot \mathrm{dL}-1$ or on lipid-lowering medication were used to identify high cholesterol. Diabetes was defined as fasting glucose $\geq 100 \mathrm{mg} \cdot \mathrm{dL}-1$ confirmed by measurements on at least 2 separate occasions or on anti-diabetic medication. Obesity was defined as body mass index (BMI) $\geq 30 \mathrm{~kg} / \mathrm{m2}$.

The exclusion criteria were history of hematological disorder, impaired coagulation tests, renal and hepatic failure, antiphospholipid antibody positivity, active infectious disease, chronic obstructive lung disease. None of the patients and controls took oral anticoagulant or antiaggregan drugs. The study protocol was approved by the local ethics committee of the university. In further analysis, the patients were divided into subgroups based on the presence or absence of CRF, and having active or inactive disease status. Low disease activity was defined as Bath Ankylosing Spondylitis Disease Activity Index (BASDAI) $<4$, while moderate-to-high disease activity was defined as BASDAI $\geq 4$. 
Table 1. Disease activity score and laboratory values of the participants

\begin{tabular}{llll}
\hline & AS patients & Healthy controls & $p$ value \\
\hline$n$ & 152 & 55 & \\
Age & $40 \pm 10.7$ & $38.8 \pm .3$ & 0.528 \\
Gender (Male/Female) & $103 / 49$ & $37 / 18$ & 0.99 \\
PLT & $309.8 \pm 97.3$ & $264.4 \pm 60.6$ & 0.01 \\
MPV & $8.13 \pm 1.3$ & $7.65 \pm 1.07$ & 0.026 \\
\hline
\end{tabular}

AS: Ankylosing spondylitis, BASDAl: Bath Ankylosing Spondylitis Disease Activity Index; ESR: erythrocyte sedimentation rate; CRP: C-reactive protein; PLT: platelet count; MPV: mean platelet volume.

After collection of blood samples in the potassium-ethylenediaminetetraacetic acid tubes (dipotassium EDTA tube), Mindry BC-6800 automated blood cell analyzer (P.R.C.) was used to measure complete blood count within 2 hours after veni-puncture as the laboratory policy to avoid EDTA induced swelling. The normal range of MPV values in our laboratory were between 6.5-11.6 fl.

\section{Statistical analysis}

The Statistical Package for the Social Sciences (SPSS Inc, Chicago, IL, USA) 18.0 was used for statistical analysis. Normality of the distribution was evaluated with Kolmogorov-Smirnov test. Continuous variables were expressed as mean $( \pm)$ standard deviation (SD). Student's $t$ test was used to compare continuous variables with normal distribution and Mann Whitney $U$ test was used to compare the rest. To evaluate the relationship between study parameters, Pearson or Spearman correlation tests were used where appropriate. All $p$ values were two-sided and a $p$ value of $<0.05$ was considered as statistically significant.

\section{RESULTS}

Mean age, gender distribution, mean PLT and MPV values, the significance of the differences between AS patients and healthy controls were demonstrated in Table 1. Of the 152 AS patients 56 (37\%) were using an antiTNFa agent, 94 (62\%) had $\geq 1$ cardiovascular risk factor: (46 (30\%) had smoking habitus, 11 (7\%) diabetes mellitus, $23(15 \%)$ hyperlipidemia, 13 (9\%) hypertension, and $43(28 \%)$ patients were obese). No patients had clinically overt atherosclerotic heart disease. Mean disease duration was $11.4 \pm 8.8$ years. $65(43 \%)$ patients had active disease with a BASDAl score $\geq 4$. Mean ESR was $21.5 \pm 21.5$ $\mathrm{mm} / \mathrm{h}$, mean CRP was $10.05 \pm 14.0 \mathrm{mg} / \mathrm{L}$ and mean BASDAI score was $3.3 \pm 2.2$ in patients with AS. The correlations of BASDAI with ESR and CRP were significant $(r=0.257$, $\mathrm{p}=0.001$ and $\mathrm{r}=0.214, \mathrm{p}=0.008$ respectively). MPV showed no significant association with any disease activity indicis (BASDAI, ESR, CRP) ( $p>0.05)$. However, the patients with high CRP had lower MPV levels $(7.86 \pm 1.32$ vs. $8.33 \pm 1.27 ; p=0.014)$. MPV was negatively correlated with PLC $(r=-0.197, p=0.015)$. PLC was positively correlated with CRP and ESR $(r=0.588, p=0.001$ and $r=0.550$, $\mathrm{p}=0.001$ respectively) but the correlation with BASDAI was not significant $(p=0.355)$.

Despite the mean BASDAl score of the AS patients using an anti-TNF agent was significantly lower than those using non-steroidal anti-inflammatory drugs \pm sulfasalazine $(2.55 \pm 2.5$ vs. $3.75 \pm 1.8 ; p=0,001)$, MPV was not significantly differing between patients using an antiTNF agent and those on different treatment regimen. Furthermore, there was no significant difference in PLT and MPV between AS patients with active and inactive state $(p=0.304$ and $p=0.315$, respectively). BASDAl score of patients with at least one cardiovascular risk factor was significantly higher than those of without any traditional CRF (3.61 \pm 2.21 vs. $2.81 \pm 1.98 ; p=0.035)$. The difference in PLT and MPV between AS patients with and without CRF's was not significant $(p=0.650$ and $p=0.938$, respectively), while mean MPV and PLT levels in the patients with at least one CRF was higher than healthy controls $(8.13 \pm 1.3$ vs. $7.65 \pm 1.1 ; p=0.047$ and $305.3 \pm 89.3$ vs. $264.4 \pm 60.6 ; p=0.022$ ).

\section{DISCUSSION}

Principle findings of this study were 1- MPV level in AS patients was higher compared to healthy controls, 2MPV and PLT levels in AS patients with at least on one traditional CRF were not higher compared to patients without any risk factor, 3- MPV showed no significant as- 
sociation with any disease activity indicis and there was no significant difference in MPV between AS patients with active and inactive state. Increased risk of cardiovascular disease and CRF's in chronic inflammatory diseases are associated with chronic systemic inflammation (6-8). In present study, more than half of the patients had one or more traditional CRF, while no patient had clinically overt cardiovascular disease. Furthermore, disease activity score of patients with at least one cardiovascular risk factor was also significantly higher than those of without any CRF.

In accordance with the findings of the study by Yazıcı et al. (15), MPV level in AS patients was higher compared to healthy controls. MPV and PLT levels in AS patients with at least on one traditional CRF were not higher compared to patients without any risk factor. There was no significant difference in MPV between patients with and without obesity; with and without hypertension; with and without diabetes mellitus; with and without hyperlipidemia, and with and without smoking. In contrast, increased MPV has been found in the patients with CRF's (17-22). This may be partially explained with the fact that the patients with hypertension, hyperlipidemia and diabetes might be under control with appropriate treatment and this may reverse MPV and PLT values. In addition, Kutlucan et al. (28), also found that presence of metabolic syndrome and its components do not constitute a difference in MPV values in obese patients with a BMI $30 \mathrm{~kg} / \mathrm{m}^{2}$ or more. In a previous study including 30 active AS patients, MPV and BASDAI scores were found to have no correlation initially. After treatment, MPV values increased and BASDAl scores decreased and they had a statistically significant negative correlation (26). However, in the study by Yazıcl et al. (15) including 68 AS patients, it was reported that increased platelet activity was reduced by both anti-TNF a and conventional therapy as the MPV and PLT values were decreased and there was a positive correlation with BASDAI. In the present study, MPV showed no significant association with ESR, CRP and BASDAI and there was no significant difference in MPV between AS patients with active and inactive state. Although mean BASDAI score of the patients on anti-TNF therapy was significantly lower, mean MPV of these patients was not significantly lower than those not treated with anti-TNF therapy. The study was retrospective in nature and did not include follow-up data. Therefore, we were not able to monitorize the changes in MPV and PLT values and evaluate the changes in disease activity indicis. Nevertheless, this study included larger number of AS patients and controls compared to previous ones.

The results of the studies evaluating MPV and its' association with disease activity have conflicting results. Increased pro-inflammatory cytokines and acute phase reactants can supress platelet size and decrease MPV by affecting megakaryopoesis and and platelet release from bone marrow (14). On the other hand, larger platelets are known to include pro-inflammatory and thrombotic agents and more reactive $(11,12,29,30)$. Most probably this may be explained with the time dependent changes of MPV during different inflammation phases (24). In acute inflammation the overproduction and release of platelets from bone marrow may lead smaller sized platelets while in chronic inflammation period platelets containing thrombogenic and pro-inflammatory cytokines with larger size may predominate resulting with increased MPV. To conclude, overall, AS patients have higher MPV than healthy controls indicating higher risk of cardiovascular involvement and atherosclerosis. AS alone may be responsible of this risk increment instead of traditional CRF's.

\section{REFERENCES}

1. Bodnár N, Kerekes G, Seres I, et al. Assessment of subclinical vascular disease associated with ankylosing spondylitis. J Rheumatol 2011;38:723-9.

2. Peters MJ, van Eijk IC, Smulders YM, et al. Signs of accelerated preclinical atherosclerosis in patients with ankylosing spondylitis. J Rheumatol 2010;37:161-6.

3. Han C, Robinson DW Jr, Hackett MV, Paramore LC, Fraeman $\mathrm{KH}$, Bala MV. Cardiovascular disease and risk factors in patients with rheumatoid arthritis, psoriatic arthritis, and ankylosing spondylitis. J Rheumatol 2006;33:2167-72.

4. Heeneman S, Daemen MJ. Cardiovascular risks in spondyloarthritides. Curr Opin Rheumatol 2007;19:358-62.

5. Peters MJ, Van Der Horst-Bruinsma IE, Dijkmans BA, Nurmohamed MT. Cardiovascular risk profile of patients with spondylarthropathies, particularly ankylosing spondylitis and psoriatic arthritis. Semin Arthritis Rheum 2004;34:585-92.

6. Van Halm VP, Van Denderen JC, Peters MJ, et al. Increased disease activity is associated with a deteriorated lipid profile in patients with ankylosing spondylitis. Ann Rheum Dis 2006;65:1473-7

7. Papadakis JA, Sidiropoulos PI, Karvounaris SA, et al. High prevalence of metabolic syndrome and cardiovascular risk factors in men with ankylosing spondylitis on anti-TNFalpha treatment: correlation with disease activity. Clin Exp Rheumatol 2009;27:292-8. 
8. Caliskan M, Erdogan D, Gullu H, et al. Impaired coronary microvascular and left ventricular diastolic functions in patients with ankylosing spondylitis. Atherosclerosis 2008; 196:306-12.

9. Weyrich AS, Lindemann S, Zimmerman GA. The evolving role of platelets in inflammation. $J$ Thromb Haemost 2003; 1:1897-905.

10. Elsenberg EH, van Werkum JW, van de Wal RM, et al. The influence of clinical characteristics, laboratory and inflammatory markers on 'high on-treatment platelet reactivity' as measured with different platelet function tests. Thromb Haemost 2009;102:719-27.

11. Toplak H, Wascher TC. Cardiovascular risk factors in obesity. Influence of weight reduction on platelet volume: Different effects of hypocaloric diet and a very low caloriediet. Eur J Clin Invest 1994;24:778-80.

12. Pereg D, Berlin T, Mosseri M. Mean platelet volume on admission correlates with impaired response to thrombolysis in patients with ST-elevation myocardial infarction. Platelets 2010;21:117-21.

13. Martin JF, Bath PM, Burr ML. Influence of platelet size on outcome after myocardial infarction. Lancet 1991;338:1409-11.

14. Bath P, Algert C, Chapman N, et al. PROGRESS Collaborative Group. Association of mean platelet volume with risk of stroke among 3134 individuals with history of cerebrovascular disease. Stroke 2004;35:622-6.

15. Yazici S, Yazici M, Erer B, et al. The platelet indices in patients with rheumatoid arthritis: mean platelet volume reflects disease activity. Platelet 2010;21:122-5.

16. Canpolat F, Akpinar H, Eskioğlu F. Mean platelet volume in psoriasis and psoriatic arthritis. Clin Rheumatol 2010;29:325-8.

17. Zuberi BF, Akhtar N, Afsar S. Comparison of mean platelet volume in patients with diabetes mellitus, impaired fasting glucose and non-diabetic subjects. Singapore Med J 2008;49:114-6.

18. Cao X, Xie X, Zhou J, Yang $P$, Wang $Y$, Chen Z. Increased platelet volume in a general population with prehypertension: a cross-sectional study of 80545 participants from China. Hypertens Res 2012;35:903-8.
19. Varol E, Akcay S, Icli A, et al. Mean platelet volume in patients with prehypertension and hypertension. Clin Hemorheol Microcirc 2010;45:67-72.

20. Coban E, Afacan B. The effect of rosuvastatin treatment on the mean platelet volume in patients with uncontrolled primary dyslipidemia with hypolipidemic diet treatment. Platelets 2008;19:111-4.

21. Coban E, Yilmaz A, Sari R. The effect of weight loss on the mean platelet volume in obese patients. Platelets 2007; 18:212-6.

22. Varol E, Icli A, Kocyigit S, Erdogan D, Ozaydin M, Dogan A. Effect of smoking cessation on mean platelet volume. Clin Appl Thromb Hemost 2013;19:315-9.

23. Acikgoz N, Karincaoğlu $Y$, Ermiș N, et al. Increased mean platelet volume in Behçet's Disease with thrombotic tendency. Tohoku J Exp Med 2010;221:119-23.

24. Gasparyan AY, Ayvazyan L, Mikhailidis DP, Kitas GD. Mean platelet volume: a link between thrombosis and inflammation? Curr Pharm Des 2011;17:47-58.

25. Jurcuț $C$, Jurcuț $R$, Caraiola $S$, et al. Platelet histogram indices and cardiovascular disease in patients with rheumatoid arthritis. Rom J Intern Med 2010;48:51-5.

26. Kisacik B, Tufan A, Kalyoncu $U$, et al. Mean platelet volume (MPV) as an inflammatory marker in ankylosing spondylitis and rheumatoid arthritis. Joint Bone Spine 2008;75:291-4.

27. van der Linden S, Valkenburg HA, Cats A. Evaluation of diagnostic criteria for ankylosing spondylitis. A proposal for modification of the New York criteria. Arthritis Rheum 1984;27:361-8.

28. Kutlucan A, Bulur S, $K r$ S, et al. The relationship between mean platelet volume with metabolic syndrome in obese individuals. Blood Coagul Fibrinolysis 2012;23:388-90.

29. Park Y, Schoene N, Harris W. Mean platelet volume as an indicator of platelet activation: methodological issues. Platelets 2002;13:301-6.

30. Chu SG, Becker RC, Berger PB, et al. Mean platelet volume as a predictor of cardiovascular risk: a systematic review and meta-analysis. J Thromb Haemost 2010;8:148-56. 